\title{
PERSEPSI WARIS MASYARAKAT TRANSMIGRASI DI KAMPUNG ARSO VII KABUPATEN KEEROM PROPINSI PAPUA PERSPEKTIF HUKUM WARIS ISLAM
}

\author{
Oleh. Muhammad Zainal Abidin \\ Kel. Yabansai, Dis. Heram, Kota Jayapura, Provinsi Papua, Indonesia \\ Fakultas Syariah, IAIN Fattahul Muluk Papua \\ email: mzainalabidin86@yahoo.com
}

Article history:

Received: $12-08-2020$

Revised: $18-08-2020$

Accepted: $24-08-2020$

\begin{abstract}
This research examines the perception of inheritance law in the transmigration community. Given that in social life, transmigration communities are multicultural, consisting of various ethnic groups and their respective cultural patterns, which come from their place, environment and social conditions of origin. Including the issue of inheritance law in the transmigration area which has its own uniqueness. The purpose of this research is to obtain information related to people's perceptions of inheritance law that applies in accordance with the customs and traditions of society. This study used a descriptive qualitative method, with a sociological approach to the perception of the transmigration community. The results of the research conducted, it can be concluded that the public perception of inheritance, namely assets that are distributed before the heir dies by means of deliberation to obtain consensus which is witnessed by the family and divided by appointment of inheritance to the heirs.
\end{abstract}

\section{Keywords: Inheritance Law; Transmigration Community; Inheritance Perception.}

\begin{abstract}
Abstrak
Penelitian ini mengkaji persepsi hukum waris pada masyarakat transmigrasi. Mengingat dalam kehidupan sosial, masyarakat transmigrasi yang multikultural, terdiri dari berbagai suku dan corak budaya masing-masing, yang berasal dari tempat, lingkungan dan kondisi sosial asalnya. Termasuk permasalahan hukum waris di daerah transmigrasi yang memiliki keunikan tersendiri. Tujuan penelitian ini adalah mendapatkan informasi terkait persepsi masyarakat terhadap hukum waris yang berlaku sesuai dengan kebiasaan dan tradisi masyarakat. Penelitian ini menggunakan metode kualitatif deskriptif, dengan pendekatan sosiologi persepsi masyarakat transmigrasi. Hasil penelitian yang dilakukan dapat disimpulkan bahwa persepsi masyarakat terhadap harta waris yaitu harta yang dibagikan sebelum pewaris meninggal dunia dengan cara musyawarah untuk mendapatkan mufakat yang disaksikan oleh keluarga dan dibagi dengan cara penunjukan harta waris kepada ahli waris.
\end{abstract}

Kata Kunci : Hukum Waris; Masyarakat Transmigrasi; Persepsi Waris. 


\section{A. Pendahuluan}

Kematian merupakan hal yang pasti dialami oleh seluruh mahluk dalam kehidupan ini. Sehingga sangatlah penting mengkaji dan mempelajari hukum waris. Hukum waris sendiri memiliki banyak persepsi yang berbeda. Di dalam Islam hukum waris termasuk dalam cakupan fikih muammalah yang merupakan bagian dari syariat Islam. Olehnya itu, al-Qur'an sebagai pedoman hidup umat Islam telah merincikan hukum waris dari pada hukum-hukum lainnya.

Secara umum kewarisan merupakan persoalan harta benda yang ditinggalkan kepada ahli waris, hukum waris merupakan bentuk keadilan yang diajarkan oleh syariat Islam. Oleh sebab itu, Selama masih ada kehidupan manusia di dunia ini, hukum kewarisan akan tetap eksis, sebagai sebuah keniscayaan dalam mengatur perpindahan kepemilikan harta kekayaan.

Selain itu, masalah waris dalam Islam tidak hanya merupakan perpindahan kepemilikan harta kekayaan saja, namun merupakan ketaatan terhadap hukum agama (syariat). Secara definisi, hukum kewarisan Islam mengatur harta peninggalan dari seseorang yang telah meninggal dunia, ahli waris dan bagian besaran yang diperoleh terhadap harta. ${ }^{1}$

Telah dijelaskan mengenai pembagian waris yatiu dalam QS. al-Nisaa ayat: 11-12, yang menjelaskan bagian masing-masing ahli waris, seperti anak perempuan dan anak laki-laki, ayah, ibu, istri atau suami, saudara-saudari dan ahli waris yang lain, bagian-bagian itu diistilahkan dengan furudhul muqaddarah. Berdasarkan ayat tersebut, kemudian dimasukkan ke dalam Kompilasi Hukum Islam (KHI) yang menjadi bahan hukum materil pada Peradilan Agama di Indonesia.

Di Indonesia sendiri, terdapat bermacam-macam sistem hukum kewarisan yang berlaku bagi warga negara, yaitu: sistem hukum kewarisan perdata barat, sistem hukum kewarisan adat dan sistem hukum kewarisan Islam. ${ }^{2}$ Sistem hukum kewarisan barat berlaku kepada golongan penduduk yang tunduk terhadap perdata

\footnotetext{
${ }^{1}$ Desti Budi Nugraheni dan Haniah Ilhami, Pembaharuan Hukum Kewarisan Islam di Indonesia, (Yogyakarta:Gadjah Mada University Press, 2014), h.8.

${ }^{2}$ Idris Ramulyo, perbandingan Pelaksanaan Hukum Kewarisan Islam Dengan Kewarisan Menurut Kitab Undang-Undang Hukum Perdata (BW), (Jakarta:Sinar Grafika,2000), h. 15.
} 
barat, dan hukum kewarisan adat berlaku bagi warga yang tunduk terhadap hukum adat. Sedang, hukum kewarisan Islam berlaku untuk warga negara Indonesia (WNI) yang beragama Islam.

Hasil observasi, memperlihatkan masih banyak tradisi pembagian waris dengan cara pembagian secara adat-kebiasaan masyarakat, seperti anak pertama diberikan lahan dan anak terakhir diberi pekarangan rumah dengan harapan anak terakhir yang akan merawat kedua orang tuanya hingga meninggal dunia. Adatkebiasaan masyarakat tersebut sebelumnya, lazimnya sesuai dengan bentuk sistem kekeluargaan yang dianut dalam masyarakat Indonesia, yang terbagi menjadi Patrilineal (Garis keturunan laki-laki) Matrilineal (Garis keturunan perempuan) dan Parental (campuran). ${ }^{3}$

Selain sistem kekerabatan tersebut, dalam kehidupan masyarakat transmigrasi, perbedaan tempat, lingkungan dan kondisi sosial lainnya ikut mempengaruhi perbedaan corak budaya dan adat masing-masing. Sehingga masyarakat pun memiliki corak budaya dan adat hukum waris yang berbeda di daerah transmigrasi di wilayah Papua.

Penelitian ini merupakan penelitian yang dilakukan pada masyarakat transmigrasi yang ada di wilayah Papua. Terdapat hal menarik dalam sistem pembagian harta warisan pada masyarakat transmigrasi yang ada di wilayah Papua, yang membagikan harta waris pada saat si pemilik harta masih hidup. Hal tersebut yang mendorong penulis untuk mengetahui lebih jauh "Persepsi Waris Masyarakat Transmigrasi di Kampung Arso VII Kabupaten Keerom Propinsi Papua" dengan memakai perspektif hukum waris Islam.

\section{B. Metode Penelitian}

Jenis penelitian yang digunakan dalam penelitian yaitu kualitatif dengan mengumpulkan data secara alami dengan cara observasi langsung di wilayah transmigrasi, untuk mendapatkan pengamatan secara mandiri, kemudian melakukan wawancara kepada narasumber yang mengetahui hal-ihwal hukum waris adat, yang dilakukan masyarakat transmigrasi. Selanjutnya yaitu 
mendokumentasikan dalam bentuk kartu data, sehingga dapat diolah dan dipertanggung jawabkan secara ilmiah.

Lokasi penelitian bertempat di aerah Transmigrasi Arso VII Kabupaten Keerom yang berada di Propinsi Papua. Responden atau informan terdiri dari masyarakat transmigrasi yang mengetahui adat waris yang digunakan serta tokoh masyarakat yang dianggap sebagai tokoh dan mengetahui adat serta tradisi waris yang berlaku dalam masyarakat tersebut.

Analisis data dengan teknik induksi, serta dengan pendekatan pendekatan sosiologis, yang mengungkap pertimbangan dan persepsi masyarakat dalam memahami dan menerapkan hukum waris Islam, menurut pendapat atau persepsi masyarakat yang beragama Islam secara umum.

\section{Pembahasan}

\section{Ketentuan Hukum Kewarisan Islam}

Terminologi waris menurut bahasa memiliki arti pusaka atau harta peninggalan, sedangkan menurut istilah hukum waris Islam atau ilmu Faraidh, yang mempelajari masalah waris dan perhitungan perpindahan harta waris dari pemilik hak pusaka/harta waris kepada orang-orang yang berhak mendapatkannya serta besaran bagian yang mereka dapatkan. ${ }^{4}$

Senada dengan itu, dalam Kompilasi Hukum Islam (KHI) pasal 171 hururf (a), dijelaskan bahwa hukum waris merupakan hukum yang mengatur tentang pemindahan hak atas kepemilikan harta yang ditinggalkan pewaris, menentukan kepada siapa yang berhak menjadi ahli waris dan hak bagiannya masing-masing ahli waris. ${ }^{5}$ Peninggalan harta waris yang dimaksud yaitu segala sesuatu yang ditinggalkan oleh pewaris, dapat berupa harta atau lainnya, termasuk hutang piutang pewaris. ${ }^{6}$

Hukum waris Islam secara umum, dan KHI secara khusus, bersumber dari al-Qur'an, hadis, Ijma, dan Qiyas. ${ }^{7}$ Dari sumber hukum tersebut, diungkapkan

${ }^{4}$ Hidayat Budi Ali, Memahami Dasar-dasar Ilmu Fara'id, (Bandung, Angkasa, 2009), h. 11.

${ }^{5}$ Kompilasi Hukum Islam (t.t: Permata Press), h. 53. 1995), h. 33.

'Muhammad Ali Ash-Shabuni, “Pembagian Waris Menurut Islam”.'Jakarta: Gema Insani Press,

7Muhammad daud Ali, Hukum Islam, (Jakarta, Raja Grafindo, 2011), h. 73. 
oleh para ulama, bahwa ada beberapa asas-asas yang menjadi prinsip utama dalam hukum kewarisan Islam. ${ }^{8}$ Misalnya seperti asas Ijbari yaitu, asas yang berlaku secara otomatis pada peralihan harta dari pewaris kepada ahli waris, tanpa dipengaruhi oleh pewaris maupun ahli waris. Ada dua aspek dalam Asas Ijbari yaitu pengalihan harta yang pasti terjadi setelah meninggal dunia dan jumlah hak dalam harta yang telah ditentukan bagiannya kepada ahli waris. ${ }^{9}$

Asas bilateral yaitu, mengandung arti bahwa seseorang menerima hak waris dari kedua belah pihak, yaitu dari jalur kerabat keturunan laki-laki dan dari jalur kerabat keturunan perempuan. Oleh karena asas bilateral ini, maka terdapat pengelompokan ahli waris dalam hukum waris Islam, yaitu golongan laki-laki dan golongan perempuan serta golongan ahli waris berdasarkan hubungan perkawinan. $^{10}$

Asas individual mengandung arti bahwa harta waris dapat dibagi-bagi pada masing-masing ahli waris untuk dimiliki secara individu. Serta, asas keadilan berimbang merupakan keseimbangan antara hak dan kewajiban dalam menetapkan bagian warisan. Dan yang terakhir asas akibat kematian, memiliki makna yaitu bahwa ahli waris mendapatkan harta waris dari pewaris atas kematian pewaris. Peralihan harta tersebut baru terjadi setelah pewaris meninggal dunia. Sehingga tidak ada harta waris sebelum pewaris meninggal dunia dan tidak mengenal kewarisan atas dasar wasiat yang dibuat oleh pewaris ketika masih hidup di dunia.

Selain itu, keberadaan rukun dalam hukum waris merupakan salah satu rangkaian yang harus dilalui dari setiap perkara. Suatu perkara pembagian waris dikatakan tidak sah atau tidak sempurna jika rukun dalam suatu perkara tersebut tidak terpenuhi. Rukun waris Islam ada 3 (tiga) yaitu: harta warisan (maurus), pewaris (Muwaris), ahli waris (Waris). ${ }^{11}$

${ }^{8}$ Hilman Hadikusumo, Hukum Waris Indonesia Menurut Perundangan Hukum Adat, Hukum Agama Hindu dan Islam, (Bandung, Citra Aditya Bakti, 1991), h.. 21.

${ }^{9}$ Aulia Mutiah, Hukum Islam : Dinamika Seputar Hukum Keluarga, (Yogyakarta, PT. Pustaka Baru, 2016), h. 147.

${ }^{10}$ Muhamad Daud Ali, Hukum Islam..., h. 316.

${ }^{11}$ Hasbi Ash-Shiddiqy, Fiqih Mawaris untuk Warisan dalam Masyarakat Islam, Jakarta : Bulan Bintang , 1973), h. 28. 
Sedangkan keberadaan syarat waris dalam kewarisan Islam, terdiri dari tiga syarat, yaitu: meninggalnya seorang pewaris, seseorang telah meninggal dan diketahui oleh ahli waris atau meninggl dunnia secara hukmiy; adanya ahli waris yang masih hidup; seluruh ahli waris diketahui secara pasti termasuk jumlah bagian masing-masing ahli waris. ${ }^{12}$

Hal lain yang menjadi ketentuan dalam hukum waris yaitu sebab-sebab yang menjadikan seseorang mendapatkan harta waris dari pewarisnya. Ada 3 (tiga) sebab yaitu: ikatan nasab, ikatan perkawinan, dan ikatan kerabat karena sebab al-Wala. Sedang, adapula beberapa sebab yang menghalangi kewarisan dalam Islam, yaitu: perbedaan agama, sebab perbudakan dan pembunuh pewarisnya. $^{13}$

Permasalahan harta warisan juga menjadi perhatian dalam hukum waris Islam. Terdapat beberapa tahapan agar semua harta yang ditinggalkan oleh pewarisnya dapat beralih kepada ahli waris, yaitu telah bersih dari kewajibankewajiban keagamaan dan keduniaan. ${ }^{14}$ Kompilasi Hukum Islam, Pasal 171 Huruf (e) mendefinisikan harta waris adalah harta bawaan ditambah bagian dari harta bersama setelah digunakan untuk keperluan perawatan selama sakit, sampai meninggalnya, biaya pengurusan jenazah dan pemberian untuk kerabat. ${ }^{15}$

\section{Persepsi Waris masyarakat Transmigrasi di Papua}

Secara terminologi persepsi merupakan penyimpulan informasi-informasi dan menafsirkan pesan melalui pengalaman tentang objek, sebuah peristiwa, atau hubungan-hubungan yang diperoleh. ${ }^{16}$ Persepsi merupakan proyeksi yang dipikirkan sehingga kita dapat mengamati objek tersebut dan ditangkap menggunakan panca indra. ${ }^{17}$ Sehingga persepsi merupakan penafsiran dari pemahaman suatu peristiwa atau kejadian melalui pengetahuan sehingga menimbulkan anggapan atau penafsiran terhadap sesuatu tersebut.

\footnotetext{
${ }^{12}$ Facthur Rahman, , Syarat-syarat Waris, (Bandung: CV Pustaka Setia), 1981, h.. 79.

${ }^{13}$ Muhammad Ali Ash-Shabuni, "Pembagian Waris Menurut Islam..., h. 38-39.

${ }^{14}$ Hilman Hadikusumo, Hukum Waris Indonesia..., h. 51.

15Zainuddin Ali, Pelaksanaan Hukum Waris di Indonesia, Jakarta: Sinar Drafika, 20080, h. 9. h. 50 .

16Jalaluddin Rahman, Psikologi Komunikasi, (Bandung: PT. Remaja Rosda Karya Offset, 2015),

${ }^{17}$ Sarlito Wirawan Sarwono, Pengantar Umum Psikologi, Jakarta, Bulan Bintang, 1975, Hal. 44
} 
Masyarakat transmigrasi di Papua secara keseluruhan tidak menggunakan cara sebagaimana hukum kewarisan Islam dalam membagikan harta warisan, masyarakat menggunakan adat-kebiasaan dan kekeluargaan dengan pembagian yang disepakati oleh para ahli waris dan dibagi oleh pewaris sendiri sebelum meninggal dunia.

Waktu pelaksanaan pembagian harta waris, serta penyerahan harta waris tidak dilakukan setelah wafatnya pewaris, tetapi proses berlangsung pada saat pewaris masih hidup. Hal ini dilakukan untuk menghindari terjadinya perselisihan dan kecemburuan di antara ahli waris, pewaris telah mengalihkan harta kepada ahli warisnya dengan berbagai pertimbangan.

Ha ini sebagaiaman penjelasan bapak Aldi selaku masyarakat Sulawesi yang bertransmigrasi, saat wawancara beliau memberikan penjelasan sebagai berikut:

"Masyarakat Sulawesi-Selatan dalam membagi harta waris, kebanyakan memilih pembagian warisan dengan musyawarah dan membagi rata harta yang akan diwariskan, dan disaksikan oleh keluarga-keluarga terdekat. Setelah semua disetujui oleh semua ahli waris yang ada, maka kesepakatan antara semua ahli waris itu di anggap sah, karena semuanya telah bersepakat. Pembagian waris di masyarakat Sulawesi-Selatan tidaklah sesulit seperti apa yang telah dijelaskan oleh hukum waris Islam. Orangorang yang berhak menerima harta warisan hanyalah keluarga terdekat dari pewaris, terutama adalah anak-anaknya. Saudara-saudara dari pewaris itu ikut mendapatkan harta waris jika pewaris tidak mempunyai anak semasa hidupnya." 18

Dari penjelasan Bapak Aldi, masyarakat cenderung membagi harta waris dengan jalan musyawarah dan membagi rata besarnya perolehan untuk masingmasing ahli waris. Keluarga terdekat diundang hanya sebatas menyaksikan dan sebagai saksi bahwa telah dilakukannya pembagian warisan kemudian telah disepakati oleh ahli warisnya.

Bapak Aldi menyatakan dalam pembagian harta waris dilaksanakan dengan cara kekeluargaan, dilaksanakan oleh orang tua melalui musyawarah bersama, yang dihadiri oleh keluarga terdekat untuk menjadi saksi atas pembagian waris yang akan dilakukan. Saat itu, orang tua dari bapak Aldi memiliki tanah

${ }^{18}$ Hasil wawancara dengan Bapak Aldi selaku Ketua Kerukunan Keluarga Sulawesi-Selatan (KKSS) Kampung Intaimelyan, pada tanggal 15 juli 2020. 
seluas 5(lima) hektar, dan saat itu yang menjadi ahli waris adalah Bapak Aldi bersama dengan 3(tiga) orang saudaranya yaitu Bapak Burhan, Bapak Suhardi, serta Ibu Dian.

Sebelum mambagiakan harta warisan, orang tua dari Bapak Aldi terlebih dahulu menyisihkan 1(satu) hektar tanah, yang akan dikelola bersama istrinya untuk biaya hidup masa tuanya. Setelah menyisihkan bagiannya, barulah kemudian tanah yang tersisa akan dibagikan secara sama rata untuk ke-4(empat) anaknya, dengan rincian: Bapak Aldi (anak laki-laki) mendapatkan satu hektar; Bapak Burhan (anak laki-laki) mendapatkan satu hektar; Bapak Suhardi (anak laki-laki) mendapatkan satu hektar; Ibu Dian (anak perempuan) mendapatkan satu hektar.

Sementara untuk tanah yang disisihkan orang tua yaitu berupa lahan 1(satu) hektar, akan diberikan kepada anak-anaknya setelah orang tua meninggal, dan bagian masing-masing sudah diputuskan saat musyawarah tersebut, namun dapat dikelola oleh anak-anaknya setelah orang tua meninggal. ${ }^{19}$

Sedangkan hasil wawancara dengan Bapak Karno dari suku jawa menjelaskan bahwa dalam pembagian waris dilakukan saat masih hidup dengan cara membagikan waris kepada ahli waris dengan cara penunjukan pembagian harta waris tanpa dibarengi hak kepemilikan secara legal.

Dalam penunjukan tersebut, ahli waris hanya dapat memanfaatkan harta waris untuk diambil manfaatnya. Sedangkan dalam hak kepemilikan belum diurus. Pembagian secara langsung dirasa lebih mudah dikarenakan kesepakatan dari hasil musyawarah keluarga dan kesepakatan para ahli waris.

Bapak Karno memiliki 2(dua) anak perempuan, dengan harta yang dibagikan yaitu berupa 2(dua) hektar tanah untuk berkebun dan pekarangan untuk rumah. Kedua anaknya tersebut bernama Ibu Hartatik dan Nyonya Kiki Astuti diberikan hak yang sama, yaitu 1 hektar tanah untuk berkebun, dan pekarangan rumah dibagi menjadi 2 (dua). Sedangkan rumah yang saat ini dihuni akan dibagikan pula kepada anaknya.

${ }^{19}$ Hasil wawancara dengan Bapak Aldi selaku Ketua Kerukunan Keluarga Sulawesi-Selatan (KKSS) Kampung Intaimelyan, pada tanggal 15 juli 2020. 
Dalam penjelasan hasil wawancara bersama bapak karno, beliau mengatakan :

"Saya punya 2 hektar untuk berkebun dan 2 pekarangan rumah, yang satunya di Koya dan satunya yang ditempati saat ini. Itu nanti saya bagi untuk anak-anak saya secara merata, biar adil. Tidak rebutan dan terjadi persoalan dikemudian hari. Saya bagikan itu, ya musyawarahkan dan dihadiri keluarga sebagai saksi, biar nanti jika kemudian hari terjadi perselisihan saya harap keluarga saya bisa meluruskan, kan sama-sama tahu". ${ }^{20}$

Dari pernyataan Bapak Karno tersebut menjelaskan bahwa dalam pembagian harta waris tidak dilakukan setelah pewaris meninggal dunia, melainkan dibagikan ketika pewaris masih hidup dan masih kental terhadap adat kekeluargaan tanpa menimbulkan konflik antara pihak ahli waris. Hal tersebut ternyata sudah digunakan secara turun temurun dari kakek dan nenek bapak Karno, sehingga bapak Karno mengikuti tradisi tersebut untuk mencapai kemaslahatan dan mengurangi kemudaratan (sengketa) dikemudian hari.

Terkait hak kepemilikan, beliau berkata bahwa akan diberikan hak kepemilikan secara legal atau sah, ketika anak-anaknya sudah berkeluarga. Saat ini hak kepemilikan telah diberikan kepada Ibu Hartati yang telah berkeluarga diberikan hak secara penuh untuk mengelola dan mendapatkan hak kepemilikan, hal tersebut dilakukan karena dianggap sudah dewasa dan berharap dapat dimanfaatkan dengan sebaik-baiknya.

Dari pemaparan tersebut sebelumnya, maka pembagian harta waris pada masyarakat transmigrasi masih menggunakan cara-cara kewarisan adatkekeluargaan dengan bermusyawarah untuk mendapatkan hasil kemaslahatan. Hasil wawancara tersebut terdapat beberapa faktor yang mempengaruhi persepsi waris oleh masyarakat, yaitu: sudah menjadi tradisi kebiasaan (adat istiadat) masyarakat; ketidaktahuan terhadap pembagian waris menurut hukum Islam; keadilan dalam persepsi masyarakat yaitu dibagi secara merata.

Masalah pembagian harta waris pada masyarakat umumnya membagikan harta warisan di luar cara yang telah ditentukan dalam al-Quran dan hadis, cara

${ }^{20}$ Hasil wawancara dengan Bapak Karno masyarakat transmigrasi asal jawa tengah, pada tanggal 17 juli 2020 
tersebut dilakukan secara turun temurun yang secara umum biasa disebut dengan istilah kekeluargaan, dalam praktiknya tentunya memiliki hasil yang berbeda dengan apa yang harusnya sudah ditetapkan dalam al-Quran dan hadis.

Dari pembahasan tersebut sebelumnya, dapat disimpulkan bahwa kebiasaan masyarakat yang terjadi dan dilakukan secara berulang-ulang, dan menimbulkan kemaslahatan, dalam ushul fiqh disebut dengan 'Urf. Kata 'Urf sendiri berkonotasi dengan kata Ma'ruf yang berarti baik, dan merupakan al-'Urf al-Shahih (tidak bertentangan dengan syariat).

Persepsi pembagian waris masyarakat transmigrasi di Kampung Arso VII secara kekeluargaan adalah boleh dilakukan. Hal ini disebabkan karena pembagian waris masyarakat transmigrasi di kampung Arso VII secara kekeluargaan merupakan kebiasaan secara turun-temurun membawa pada kemaslahatan atau kebaikan. Kemaslahatan dapat diukur dari tidak adanya komplain atau sengketa setelah pembagian harta waris kepada ahli waris baik ketika pewaris masih hidup atau sudah meninggal dunia.

\section{Kesimpulan}

Dari pemaparan tersebut sebelumnya, maka dapat disimpulkan sebagai hasil penelitian, bahwa persepsi waris dalam pandangan masyarakat transmigrasi di Kampung Arso VII Propinsi Papua, yaitu dengan cara penunjukan secara langsung ahli waris sebagai penerus kepemilikan hak harta waris, untuk diambil manfaatnya dengan cara pembagian secara mufakat berdasarkan hasil musyawarah yang disaksikan oleh keluarga. Kemudian kepemilikan harta waris diserahkan sepenuhnya ketika pewaris telah meninggal dunia.

Pembagian waris dilakukan sebelum pewaris meninggal dunia dan dilakukan penunjukkan secara langsung terkait hak harta waris kepada ahli waris sesuai dengan hasil kesepakatan agar tidak terjadi konflik atau sengketa dikemudian hari. Maka hal ini tidak bertentangan dengan hukum waris Islam (syariat), karena tujuan pensyariatan hukum waris adalah kemaslahatan bersama. 


\section{DAFTAR PUSTAKA}

Abta, Asyari. dkk. Kewarisan Dalam Islam. Bandung: CV Pustaka Setia, 2009.

Ali, Hidayat Budi. Memahami Dasar-dasar Ilmu Fara'id. Bandung: Angkasa, 2009.

Ali, Muhammad daud. Hukum Islam, Jakarta: Raja Grafindo, 2011.

Ali, Zainuddin. Pelaksanaan Hukum Waris di Indonesia. Jakarta: Sinar Drafika, 2008.

Ash-Shabuni, Muhammad Ali. Pembagian Waris Menurut Islam. Jakarta: Gema Insani Press, 1995.

Ash-Shiddiqy, Hasbi. Fiqih Mawaris untuk Warisan dalam Masyarakat Islam. Jakarta: Bulan Bintang , 1973.

Hadikusumo, Hilman. Hukum Waris Indonesia Menurut Perundangan Hukum Adat, Hukum Agama Hindu dan Islam, Bandung: Citra Aditya Bakti, 1991.

Kementerian Agama RI. Al-Qur'anul-karim, Al-Jamanatul 'Ali. Bandung: CV. Penerbit J-ART, 2007.

Mutiah ,Aulia. Hukum Islam: Dinamika Seputar Hukum Keluarga. Yogyakarta: PT. Pustaka Baru, 2016.

Nugraheni, Desti Budi dan Haniah Ilhami. Pembaharuan Hukum Kewarisan Islam di Indonesia. Yogyakarta: Gadjah Mada University Press, 2014.

Poespitsari, Ellyne Dwi. Pemahaman Seputar Hukum Waris Adat Di Indonesia. Jakarta: Prenadamedia Group, 2018.

Rafiq, Ahmad. Fiqih Mawaris. Jakarta: PT. Raja Grafindo Persada, 1998.

Rahman, Facthur. Syarat-syarat Waris. Bandung: CV Pustaka Setia, 1981.

Rahman, Jalaluddin. Psikologi Komunikasi. Bandung: PT. Remaja Rosda Karya Offset, 2015.

Ramulyo, Idris, perbandingan Pelaksanaan Hukum Kewarisan Islam Dengan Kewarisan Menurut Kitab Undang-Undang Hukum Perdata (BW), Jakarta: Sinar Grafika, 2000.

Sarwono, Sarlito Wirawan. Pengantar Umum Psikologi. Jakarta: Bulan Bintang, 1975. 